\title{
Active metal-cycling microbial communities of polymetallic nodules from the Eastern Pacific Ocean
}

\author{
JULIA M. OTTE ${ }^{*}, 1,2$, BATHUAN CAGRI YAPAN ${ }^{2}$, JESSICA \\ VOLZ $^{3}$, FELIX JANßEN ${ }^{1,2}$, MASSIMILIANO MOLARI ${ }^{2}$, \\ FRANK WENZHÖFER ${ }^{1,2}$ \\ ${ }^{1}$ HGF MPG Group on Deep Sea Ecology and Technology, \\ Alfred-Wegener-Institute Helmholtz Centre for Polar and \\ Marine Research, Germany \\ ${ }^{2}$ Max-Planck-Institute for Marine Microbiology, Germany \\ ${ }^{3}$ Marine Geochemistry, Alfred-Wegener-Institute Helmholtz \\ Centre for Polar and Marine Research, Germany \\ * correspondence: julia.otte@awi.de \& jotte@mpi-bremen.de
}

The rising demand for minerals and metals is encouraging the great international interest for alternative sources in the deep sea. Deposits of deep-sea polymetallic nodules attracted the attention for a long time because they are rich in nickel, copper, cobalt, and rare earth elements. The environmental consequences of large-scale mining of polymetallic nodules are currently less known. In 2019 the Belgian and German licence area in the Clarion-Clipperton Zone (Eastern Pacific) were studied to obtain further baseline characteristics of the $4000 \mathrm{~m}$ deep polymetallic nodule fields. Here, we present: i) diversity and distribution of the present \& active microbial communities of polymetallic nodules and ii) abundance and activity of relevant metal-cycling microorganisms by quantification of extracellular enzyme activity and $16 \mathrm{~S}$ rRNA amplicon sequencing. Further we aim to enrich potential metal-cycling microorganisms and investigate microbial metabolisms by metagenomic/-transcriptomic from polymetallic nodules. Our results may provide a new set of tools for monitoring ecosystem impacts associated with deepsea polymetallic nodule mining. New regulations are required to protect these areas from irreversible anthropogenic impacts. 